Nadiya DUBROVINA, Erika NEUBAUEROVA, Michal FABUŠ, Oksana TULAI

\title{
THE EVALUATION OF INDICES OF PUBLIC FINANCE DISTRIBUTION ON CENTRAL AND LOCAL LEVELS FOR EU COUNTRIES
}

\begin{abstract}
Nowadays the problems of optimal taxation and tax distribution are closely connected with growth of decentralization and democracy in the world, especially in EU and other countries, such as USA, Canada, etc. Many economists and analysts studied the problems of co-operation between central and local administration in the realization of the state programmes and efficiency of public services on different levels (central, regional or local). Due to the theoretical and empirical evidence it was clear that some functions of public administration on

(C) Nadiya Dubrovina, Erika Neubauerova, Michal Fabuš, Oksana Tulai, 2019.

Dubrovina Nadiya, PhD, CSc., Associate Professor, School of Economics and Management in Public Administration in Bratislava, ORCID ID 0000-0003-1346-9708, SCOPUS ID: https://www.scopus.com/ authid/detail.uri?authorld=56290102700, nadiya.dubrovina@gmail.com.

Neubauerova Erika, PdD, Associate Professor, University of Economics in Bratislava, ORCID ID: 0000-0002-6703-0314, erika.neubauerova@euba.sk.

Fabuš Michal, PhD, School of Economics and Management in Public Administration in Bratislava, ORCID ID: 0000-0002-3792-179X, michal.fabus@vsemvs.sk.

Tulai Oksana, Doctor of Economic Sciences, Professor at the S. I. Yurii Department of Finance, Ternopil National Economic University, ORCID ID: 0000-0002-5588-7046; ResearcherID: G-77032017; Scopus Author ID: 56677844000; oksana.tulai@gmail.com.
\end{abstract}


the central level are not carried out efficiently and some competences of public administration can be transferred to the local levels.

Thus, the problems of competences and public finance distribution between central level (state) and other levels (regional or local) are the main aspects to discuss in the theories of fiscal federalism and fiscal decentralization. In the theory of fiscal federalism the problem of taxes allocation between different levels of government is considered to be one of important tools for realization of stabilization and allocation functions of public finance.

It should be noted that one of the theoretical and research problems is how to evaluate the measure for financial decentralization. There are different approaches to this problem in modern research such as qualitative (for example, grouping countries based on some qualitative criteria or experts' evaluation of reforms focuse on financial decentralization) or quantitative ( a set of different ratios, geometric mean of different indicators, aggregated index, etc.). The purpose of the research is to obtain the aggregated indicators for evaluation of public finance distribution on central and local levels and to analyze the balance between these indicators for EU countries. For our research we used the idea of aggregated indicator to evaluate the measure of dependence upon central government expenditure and measure of local autonomy development. Due to the methodology for calculation of aggregated index proposed by Helwig the value of the aggregated index is varied from 0 to 1 , or from minimal possible level to maximum possible level of the generalized characteristics described by the original set of indicators. Thus, if measure of public finance dependence upon central government Int_C is more closed to 1 , then central government plays a greater role in expenditure for public finance. If measure of local autonomy Int_L is more closed to 1 , then local government has more opportunities in their revenue and expenditure. It should be noted that for the balanced position of the country on the plot the values of the Int_C and Int_L should be equal to or lie on 45 degree line. If the bundles lie upper 45 degree line it means that level of local autonomy is more expressed, and vice versa, if the bundles lie lower 45 degree line it means that level of local autonomy is less expressed. The aggregated indices Int_C and Int_L were calculated for EU countries during the period of 2002-2017 and it makes possible to evaluate the features of national fiscal policy in balance between distribution of funds for central and local levels.

\section{Key words:}

Financial decentralization, evaluation, aggregated index, central and local levels, balance. 
JEL: C43, H70.

\section{Introduction}

Nowadays the problems of optimal taxation and tax distribution are closely connected with growth of decentralization and democracy in the world, especially in EU and other countries, such as the USA, Canada, etc. (ALESINA, ARDAGNA, PEROTTI, SCHIANTARELI, 2002, 571-589; ALESINA, PEROTTI, 1997, 205-248; OECD, January 2012; Taxation Trends in the European Union. Data for the EU Member States, Iceland and Norway. 2014. Available at: http//ec.europa.eu/taxtrends). Decentralization is connected with three different but related processes: deconcentration; delegation and devolution. 26 p.):

According to definition of these processes by S. White (WHITE, 2011,

1) Deconcentration is a process whereby the central government disperses responsibilities for certain services to regional branch offices without any transfer of authority.

2) Delegation refers to a situation in which the central government transfers responsibility for decision making and administration of public functions to local governments;

3) Devolution means that the central government transfers authority for decision making, finance, and administrative management to quasi-autonomous units of local government.

S. White, G. Wright, V.Niznansky and other authors considers the main types of the decentralization, such as: political decentralization; administrative decentralization and fiscal decentralization (ALESINA, PEROTTI, 1997, 205-248; ALCIDI, GIOVANNINI, INFELISE, NÚÑEZ FERRER, 2014; OECD 2012, No. 9, January 2012., WHITE, 2011, 26 p.). Political decentralization is important, because it makes possible to develop different political institutions and their freedom, to collect citizen interests and turn them into policy decisions. Administrative decentralization concerns the administrative mechanism, where political institutions turn policy decisions into allocative outcomes through fiscal and regulatory actions. Fiscal decentralization maintains that local entities can collect taxes, undertake expenditures and rectify imbalances (BAHL, NATS, No.4, 1986; BAHL, MARTINEZ-VAZQUEZ, 2006; TIEBOUT, 1956). As V.Tanzi noted that the 
trend toward fiscal decentralization exists and was is explained by such factors as: deeping democratization and freedom; globalization and information expansion; increasing role of regional and local economies (TANZI, 2001).

Many economists and analysts studied the problems of co-operation between central and local administration in the realization of the state programmes and efficiency of public services in different level (central, regional or local). Due to the theoretical and empirical evidence it was clear that some functions of public administration on the central level are not carried out efficiently and some competences of public administration can be transferred to the local levels. So, the theory about the leading role of state in the spatial planning and regional development was not so successful and increasing problem of regional disparities observed in many countries lead to the necessarity to consider the endogenous factors of growth in the poor regions. These factors (such as local industrial potential, small business development, local taxes, etc.) as well as regional competences and capacities should stimulate the economic growth in the less developed regions. But central government can also provide some programmes, subsidies and grants to support these regions. Thus, the problems of competences and public finance distribution between central level (state) and other levels (regional or local) are the main aspects to discuss in the theories of fiscal federalism and fiscal decentralization (ALCIDI, GIOVANNINI, INFELISE, NÚÑEZ FERRER, 2014; BAHL, MARTINEZ-VAZQUEZ, 2006). In the theory of fiscal federalism the problem of taxes allocation between different levels of government is considered as one of important tools for realization of stabilization and allocation functions of public finance.

It should be noted that one of the theoretical and research problems is how to evaluate the measure for financial decentralization.

There are different approaches to this problem in modern research.

In the report «Division of powers between the European Union, member states, candidate and some potential candidate countries, and local and regional authorities: Fiscal decentralisation or federalism» written by C. Alcidi, A. Giovannini, F. Infelise and J. Núñez Ferrer (CEPS) the analysis of fiscal decentralization state is carried out for $28 \mathrm{EU}$ members and 5 candidate countries (Iceland, Montenegro, the Former Yugoslav Republic of Macedonia, Serbia and Turkey) and 3 potential candidates (Albania, Bosnia and Herzegovina and Kosovo) (ALCIDI, GIOVANNINI, INFELISE, NÚÑEZ FERRER, 2014). Authors used the quantitative and qualitative information and simple methods for calculation of such ratios as: expenditure ratio; revenue autonomy; own decentralization; transfer dependency and composite ratio.

E.Markowska-Bzducha proposed to use geometric mean of 5 indicators for the evaluation of local finance autonomy (MARKOWSKA-BZDUCHA, 2006, $\mathrm{Nr}$ 6(13), 18-21.). This set of indicators included 5 ratios: 1) expenditure of local government to total public expenditure (\%); 2) expenditure of local government to 

on central and local levels for EU countries

GDP (\%); 3) own revenue of local government to total public revenue (\%); 4) revenue from local tax and other taxes obtained by local government to total public revenue (\%); 5) investment expenditure of local government to total public expenditure (\%). According to this calculation for 2001 the highest level of local finance autonomy was observed in Sweden (32.3\%) and the lowest level of this indicator was in Malta (\%). The high values of local finance autonomy were obtained for Denmark and Finland (31.4\%), the Czech Republic (30\%) and Ireland (29\%). Such countries as Slovakia, Belgium, Germany, Great Britain and Greece had relatively low level of local finance autonomy, the calculated value were between 15\% and 20\% (MARKOWSKA-BZDUCHA, 2006, Nr 6(13), 18-21). But it should be noted that the mentioned approach for calculation of local finance autonomy based on the geometric mean has serious disadvantage when some of the partial indicators is equal to 0 .

\section{The purpose of research and methodology}

The purpose of research is to obtain the aggregated indicators for evaluation of public finance distribution on central and local levels and to analyze the balance between these indicators for EU countries.

It should be noted that the aim in multidimensional analysis is to obtain the aggregated indicator as the convolution of the values of another set of indicators. If all the variables are measured in the percentage it is possible to use geometric mean as simple aggregated value, but geometric mean has disadvantage if one of the variables is equal to 0 . One of the more advanced methodologies for the aggregated values was proposed by Helwig and used in many studies provided by Pluta et al., (KOPCZEWSKA, KOPCZEWSKI, WOJCIK, 2009, 646, ISBN 978-83-7556-150-0).

The algorithm of the aggregated index is presented in Fig.1.

For our research we used the idea of aggregated indicator to evaluate the measure of dependence upon central government expenditure and measure of the local autonomy development.

In order to measure of the dependence of public finance upon central government expenditure (Int_C) we used such indicators:

1) $\mathrm{X} 1$ - [(Subsidies, payable + capital transfers, payable + investment grants, payable +other current transfers, payable)/Expenditure] * $100 \%$;

2) X2 - [Current taxes on income and wealth, payable/Expenditure] ${ }^{*} 100 \%$;

X3 - [Property Income, payable/Expenditure] * $100 \%$;

X4 - [Social benefits other than social transfers in kind, payable/Expenditure] ${ }^{*} 100$. 
Fig. 1

The algorithm of the aggregated index according

to the method proposed by Helwig

(KOPCZEWSKA, KOPCZEWSKI, WOJCIK, 2009, 646,

ISBN 978-83-7556-150-0)

Initial set of $j$ indicators (factors) for $i$ objects $X=\left(x_{i j}\right), i=1, \bar{n} ; j=1, \bar{k}$

$i$-number of object, $j$-number of indicator (factor), $x_{i j}$-value for $j$-indicator (factor) for $i$-object

Standardization procedure

$$
\tilde{x_{i j}}=\frac{x_{i j}-\bar{x}_{j}}{s_{j}},
$$

where $x_{i j}$-standartized value for $x_{i j}, \bar{x}_{j}-$ mean for $j$ indicator (factor), $s_{j}-$ standard deviation for $j$-indicator (factor)

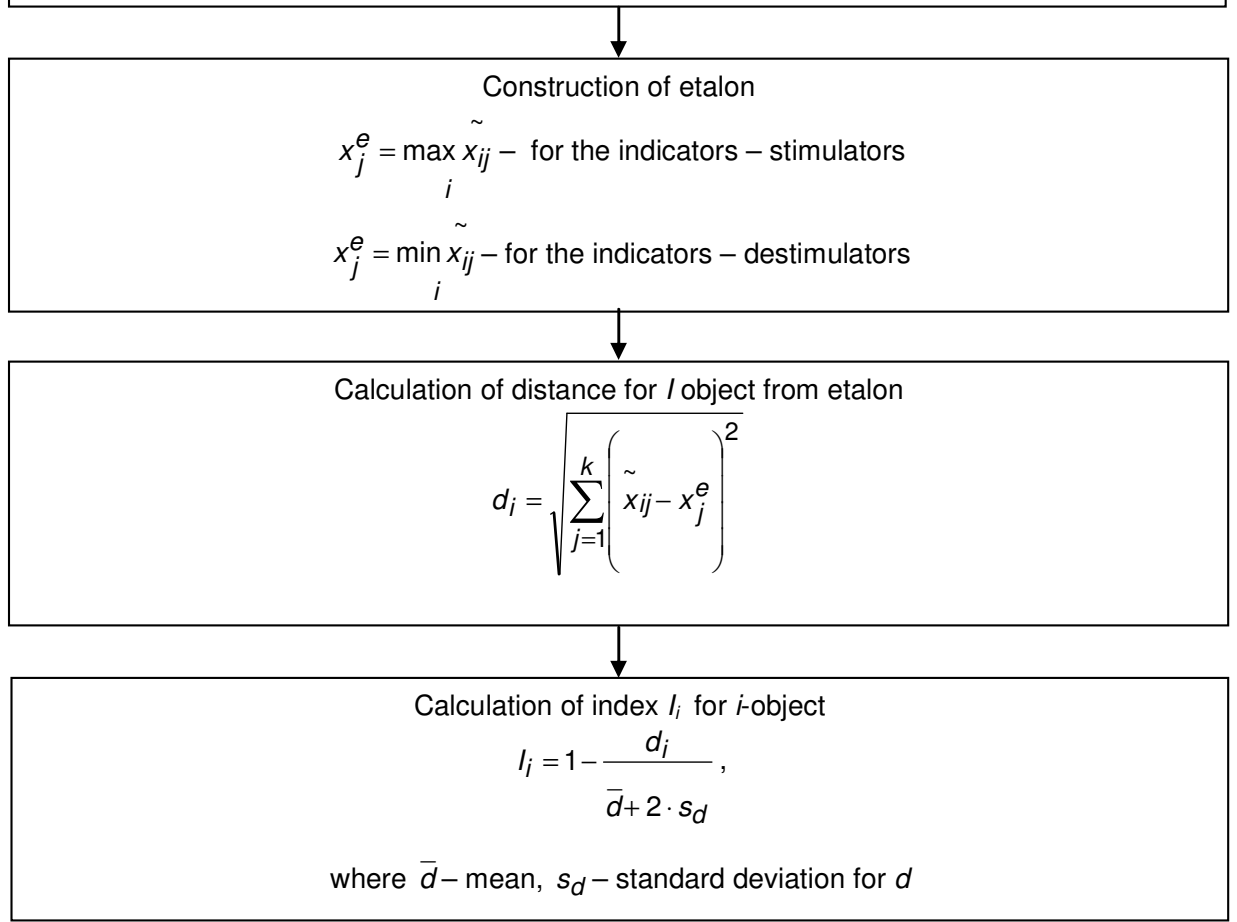



on central and local levels for EU countries

So, we used some of these indicators for cluster analysis, but aggregated index allows us to define value of one indicator, which is easy to interpret. Due to the methodology for calculation of aggregated index proposed by Helwig the value of the aggregated index is varied from 0 to 1 , or from minimal possible level to maximum possible level of the generalized characteristics described by the original set of indicators. Thus, if measure of dependence of public finance upon central government Int_C is more close to 1 , then central government plays more important role in expenditure for public finance. indicators:

For measurement of local autonomy development (Int_L) we used such

Y1 - [Taxes, receivable/Revenue $]^{\star} 100 \%$;

Y2 - [Transfers, receivable/Revenue ${ }^{\star} 100 \%$;

Y3 - [Social benefits other than social transfers in kind, payable/Expenditure] ${ }^{*} 100 \%$;

Y4 - [ Social transfers in kind, payable/Expenditure] ${ }^{\star} 100 \%$;

Y5 - [(Capital transfers, payable + other current transfers, payable + investment grant, payable)/Expenditure] $]^{\star} 100 \%$;

Y6 - [Net social contributions, receivable/Revenue $]^{\star} 100 \%$.

Thus, if measure of local autonomy Int_L is more close to 1, then local government has more opportunities in their revenue and expenditure.

\section{The main results}

For evaluation of the EU countries position we used available data from Eurostat, because database of OECD for the purpose of financial decentralization and fiscal federalism study does not contain information about all EU countries, and sometimes the statistical information in this database is not actual. That is why we proposed our own set of indicators based on the available and more actualized databases from Eurostat for the evaluation of financial decentralization and local autonomy level in different countries of EU.

In table 1 the results of the calculation of integrated indices Int_C and Int_L as well as the position of the different countries are presented in the coordinates (Int_C; Int_L) on the plot (Fig. 2). 
Table 1

The results of the calculation of the aggregated indicators for EU countries

\begin{tabular}{|c|c|c|c|c|c|c|c|c|c|c|c|c|}
\hline & \multirow{2}{*}{\multicolumn{2}{|c|}{$\frac{\text { Int_Cent } \mid \text { Int_Loc }}{2002}$}} & \multirow{2}{*}{\multicolumn{2}{|c|}{\begin{tabular}{|c|} 
Int_Cent|Int_Loc \\
2005
\end{tabular}}} & \multirow{2}{*}{\multicolumn{2}{|c|}{ Int_Cent Int_LOC }} & \multirow{2}{*}{\multicolumn{2}{|c|}{ Int_Cent|Int_LoC }} & \multicolumn{2}{|c|}{ Int_Cent|Int_Loc } & \multicolumn{2}{|c|}{ Int_Cent Int_Loc } \\
\hline & & & & & & & & & & & & \\
\hline $\mathrm{BE}$ & 0,235 & 0,396 & 0,228 & 0,37 & 0,227 & & 0,218 & 0,38 & 0,212 & & 0,192 & 0,371 \\
\hline $\mathrm{BG}$ & & & 14 & & 12 & & & & & & & \\
\hline $\mathrm{CZ}$ & & & & 274 & 276 & & & & & &, 22 & \\
\hline $\mathrm{K}$ & & & & & & & & & & & & 404 \\
\hline $\mathrm{DE}$ & & & & & 25 & & & & & & & $5<0$ \\
\hline EE & 136 & 177 &, 14 & 202 & 142 & 01 & 146 & & 136 & 0,195 & & 178 \\
\hline IE & 2 & 0,286 & & 139 & & 36 & & & & & &, 314 \\
\hline EL & 0,189 & 0,287 & 187 & 221 & 445 & 0,222 & 214 & & 193 & 0,238 & & 0,232 \\
\hline ES & 217 & 0,3 & 202 & 301 & 0,187 & 0,29 & 0,21 & 317 & 228 & 0,304 & 227 & 0,31 \\
\hline FR & 0,197 & 0,309 & 0,195 & ,337 & 0,204 & 0,337 & 0,202 & 0,341 & 194 & 0,353 & 187 & 0,363 \\
\hline $\mathrm{HR}$ & 0,15 & 0,273 & 0,153 & 287 & 0,148 & 0,281 & 0,176 & 61 & 83 & 88 & & 0,262 \\
\hline IT & 0,206 & 384 & 0,2 & 386 & 0,2 & 0,3 & 0,205 & 0,373 & 0,206 & 0,376 & 202 & 0,377 \\
\hline CY & 172 & 9 & 31 & & & & & 0,16 & & 67 & & \\
\hline LV & 125 & 0,328 & & 23 & & & & 0,2 & & 0,265 & & 0,313 \\
\hline LT & 156 & 0,2 & 0,134 & 214 & 0,139 & 0,153 & 0,185 & 0,197 & 0,181 & 0,198 &, 168 & 0,185 \\
\hline $\mathrm{LU}$ & 31 & , 22 & & 214 & & 0,214 & & 229 & 14 & 0,235 & 35 & 0,233 \\
\hline $\mathrm{HU}$ & 12 & 257 & & 265 & & 0,241 & & 216 & 184 & 0,171 & & 247 \\
\hline IT & & & & & & & & & & & & 114 \\
\hline $\mathrm{NL}$ & & & & & & 4 & & & & & & \\
\hline AT & & & & 432 & & 0,41 & & 424 & & 0,4 & & 427 \\
\hline$\overline{\mathrm{PL}}$ & 93 & 42 & & & & 0,3 & & & & 01 & & ,358 \\
\hline PT & & & & & & & & & & & & 118 \\
\hline $\mathrm{RO}$ & & 0,226 & & 272 & & $\overline{0,2}$ & & 23 & & 0,203 & 78 & 0,223 \\
\hline $\mathrm{SI}$ & 171 & 0,278 & & & & 0,3 & & & & 0,249 & 74 & 0,296 \\
\hline SK & 193 & 0,232 & 0,197 & & 0,185 & 0,185 & 0,187 & & 186 & 0,177 & 173 & 0,157 \\
\hline $\mathrm{FI}$ & 0,194 & 0,263 & 0,181 & 0,261 & 0,172 & 0,26 & 69 & 0,264 & 407 & 0,268 & 454 & 0,271 \\
\hline SE & 0,227 & 0,308 & 0,207 & 0,327 & 0,198 & 0,334 & 0,185 & 0,346 & 0,176 & 0,339 &, 168 & 0,341 \\
\hline UK & 0,199 & 0.33 & 0,193 & 0.329 & 0,198 & 0,332 & 0.21 & 0,351 & 0,201 & 0.376 & 0,202 & 0,369 \\
\hline
\end{tabular}

Source: own statistical elaboration in Excel.

In Fig. 2 the position of the EU countries for aggregated indicators Int_C and Int_L are given for the period of 2002-2017.

It should be noted that for the balanced position of the country on the plot the values of the Int_C and Int_L should be equal or lie on 45 degree line. If the bundles lie above $4 \overline{5}$ degree line it means that of local autonomy level is more expressed, and vice versa, if the bundles lay lower 45 degree line it means that of local autonomy level is less expressed. From this table it is clear that most of bundles were located above 45 degree line, it means that in most EU countries the level of local autonomy was greatly expressed. 
Fig. 2

The position of the countries in 2002-2017 for aggregated indicators Int_C and Int_L

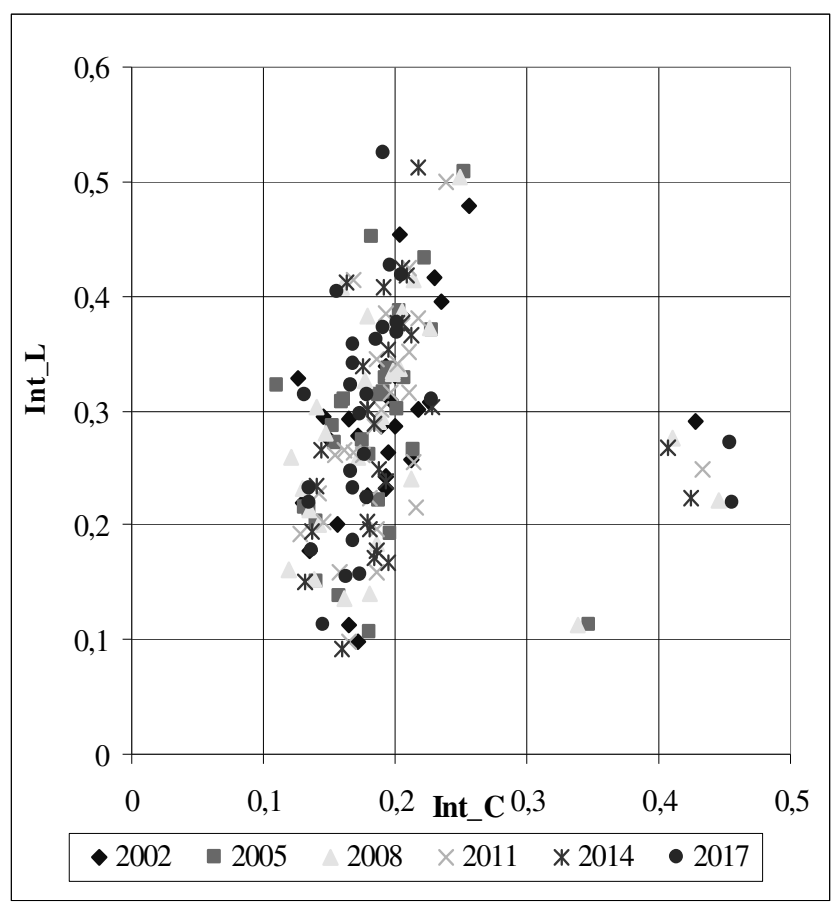

Source: own statistical elaboration in Excel

As we can see from these results, in some post socialist countries such as Bulgaria, Estonia, Lithuania in certain time period the values of measure of public finance dependence upon central government expenditure (Int_C ) and measure of local autonomy (Int_L) were close to each other. For example, the positions according to coordinates Int_C and Int_L were:

1) for Bulgaria $(0,14 ; 0,15)$ in $2005 ;(0,12 ; 0,16)$ in $2008 ;(0,128 ; 0,191)$ in 2011 and $(0,132 ; 0,151)$ in 2014 ;

2) for Estonia $(0,136 ; 0,177)$; in $2002 ;(0,136 ; 0,195)$ in $2014 ;(0,137$; 0,178 ) in 2017;

$3)$ for Lithuania $(0,139 ; 0,153)$ in $2008 ;(0,185 ; 0,197)$ in $2011 ;(0,181$; $0,198)$ in 2014 and $(0,168 ; 0,185)$ in 2017. 
Thus, it is possible to suggest that the mentioned countries followed the balanced policy in fiscal reforms and decentralization, so the levels of public finance dependence upon central government expenditure and local autonomy were developed more or less equally.

In other countries, for example, France, Italy, Portugal, Sweden the values of Int C are essentially lower than values of Int_L; thus in the mentioned countries the processes of local financial autonomy are more expressed in comparison with public finance dependence upon central government expenditure.

In such countries, as Greece and Malta it is possible to observe the essential higher values of Int_C than values of Int_L. For example, for Greece $(0,445$; $0,222)$ in crisis period of 2008; for Malta $(0,348 ; 0,114)$ in 2005 and $(0,339$; 0,114) in 2008; for Finland $(0,407 ; 0,268)$ in 2014 and $(0,454 ; 0,271)$ in 2017.

For Visegrad countries (Slovakia, the Czech Republic, Poland and Hungary) we observed some differences in the realization of reforms for financial decentralization during the period of 2002-2017.

For example, in Slovakia and Hungary the differences between values of aggregated indicators Int_C and Int_L are not so essential; we can suggest that the positions of Slovakia and Hungary are quite close to 45 degree line. Thus, the state policy is essentially balanced for the role of central government power and local autonomy. In the Czech Republic and Poland, we can see that values of Int_L are essentially higher than values of Int_C, thus the local autonomy are developing more in comparison with the central government impact.

\section{Conclusion}

For the evaluation of EU countries position on the background of fiscal decentralization development it is possible to use multi dimension statistical analyses such as cluster analysis, discriminant analysis or aggregated indices calculated by special statistical methods. In this research we used aggregated indices calculated by the method proposed by Helwig and Pluta (KOPCZEWSKA, KOPCZEWSKI, WOJCIK, 2009, 2009. 646, ISBN 978-83-7556-150-0). Application of the aggregated indices by special statistical methods allows us to evaluate the positions of SR and their dynamics on the background of the financial decentralization development in other EU countries. In this case some of the countries also provided the stable policy concerning the level of financial decentralization and did not essentially change the indicators; other in contrast, used significant changes in indicators characterizing the development level of financial decentralization and local autonomy. Thus, due to the essential positive or negative change of political and economic situation in certain countries they used more flexible policy to increase more or, vice versa, to reduce more the level of finan- 

on central and local levels for EU countries

cial decentralization. Then we analyzed the more detail position of SR on the background of Visegrad countries and found some important differences in the policy of these countries-neighbors despite fiscal decentralization and its development. Dispute the existence of some important similarities in historical heritage, economic and social development, the realization of the approach to the problem of the financial decentralization was different in Visegrad countries. Thus, institutional factors, as well as political situation and features of the modern economic and social development play an important role in the choice of selecting the appropriate model of financial decentralization in each country.

\section{References}

1. Alesina, A., Ardagna, S., Perotti, R. , Schiantareli, F. 2002. Fiscal Policy, Profits and Investment. American Economic Review 92, 571-589.

2. Alesina, A., Perotti, R. 1997. Fiscal Expansions and Adjustments in OECD Countries. Economic Policy 21., 205-248.

3. Alcidi, C., Giovannini, A., Infelise, F., Núñez Ferrer, J. 2014. Division of powers between the European Union, member states, candidate and some potential candidate countries, and local and regional authorities: Fiscal decentralisation or federalism. 2014.

4. Bahl R.W., Nats S. Public Expenditure Decentralization. In: Developing Countries//Government and Policy, No.4. 1986.

5. Bahl, R., Martinez-Vazquez, J. 2006. Sequencing Fiscal Decentralization. World Bank Policy Research Working Paper 3914. World Bank, Washington DC.

6. Kopczewska, K., Kopczewski, T., Wojcik, P. 2009. Metody ilosciowe w R. Aplikacje ekonomiczne i finansowe. Warszawa, CeDeWu. 2009. $646 \mathrm{~s}$. ISBN 978-83-7556-150-0.

7. Markowska-Bzducha, E. 2006. Samodzielnosc finansowa samorzadow terytorialnych $w$ dwudziestu piecu krajach Unii Europejskej. In: Fundusze Europejske. $\mathrm{Nr}$ 6(13). 2006. - S.18-21.

8. Nižňanský, V., Cibáková, V., Hamalová, M. 2014. Tretia etapa decentralizácie verejnej správy na Slovensku. Wolters Kluwer. VSEMVS. 2014. 231 s. ISBN 978-80-8168-138-7.

9. OECD 2012, "Income inequality and growth: The role of taxes and transfers», OECD Economics Department Policy Notes, No. 9. January 2012.

10. Tanzi, V. 2001. Pitfalls on the Road to Fiscal Decentralization. Working Paper. No. 19. Carnegie Endowment for International Peace, Washington DC. 
Vol. 18. № 4 (71) October-December 2019

ISSN 2519-4070

11. Taxation Trends in the European Union. Data for the EU Member States, Iceland and Norway. 2014. Available at: http//ec.europa.eu/taxtrends

12. Tiebout, Ch. 1956. A Pure Theory of Local Expenditures. Journal of Political Economy 64, issue 5.

13. White, S. 2011. Government Decentralization in 21 st Century. A literature review. CSIS. Center for Strategic \& International Studies. -26 p.

The article was received on November 21, 2019. 